\title{
Damu
}

LXXX

\section{Раїса Мовчан}

\section{“ТРУАИ І АНІ” ВААЕРІЯ ШЕВЧУКА (АО 80-АITТЯ ВIА АНЯ НАРОАЖЕННЯ)}

У статті йдеться про класика української літератури XX ст. Валерія Шевчука - письменника (поета, прозаїка, драматурга), історика-культуролога, літературознавця, упорядника-архівіста, перекладача, мемуариста, представника київського шістдесятництва, лідера "житомирської прозової школи", предтечі українських постмодерністів та про його різногранну літературну творчість. Увагу зосереджено на її витоках, метафізичній пов'язаності з містами Житомиром і Києвом, із українською бароковою традицією. Здійснено огляд особливостей його індивідуального стилю, великої історико-літературної, культурологічної діяльності та її значення в національному гуманітарному просторі.

Ключові слова: шістдесятник, витоки творчості, бароко, індивідуальний стиль, необароко, травестування, умовність, історіософрічність, притчовість.

Raiisa Movchan. 'Works and Days' of Valerii Shevchuk (to the 80th Anniversary of Birth)

The essay is focused on the classic of the 20th century Ukrainian literature Valerii Shevchuk and his complex and diverse literary work in various genres. He is a writer (poet, prose writer, play writer), historian of culture, literary scholar, archivist, translator, memoirist, prominent representative of Kyiv Sixtiers, leader of 'Zhytomyr prose school' and forerunner of Ukrainian postmodernists. Special attention is paid to the sources of the author's work, its metaphysical connection with Zhytomyr where he was born, and Kyiv where he has been living and writing and endured a decade of forced solitude remaining free, where he truly established himself as a Ukrainian writer. His research activity and translation work, focused on Ukrainian history and Old Ukrainian literature (particularly of the 16th-18th centuries), provoked the writer's interest in Ukrainian Baroque tradition and its transformation in his own works.

It all started with poetry, which he never stopped writing. That is why the subjective stuff is also important in his prose, which is rational in its neo-baroque basis. The essay provides a general overview of the specific features of Shevchuk's individual style, which is characterized by combination of realistic authenticity with convention or irreality, 'high' and 'low' narration style, travesty of storylines and images, parabolic technique, historiosophy, irony, etc.

Worthy of separate attention and high esteem is the scholarly work of the writer and his contribution to the general field of culture. This activity includes preparation of different anthologies and collections, numerous translations of Kyivan Rus texts into modern Ukrainian, many articles, prefaces, extensive historical and cultural studies, etc. The work of Valerii Shevchuk is important for the humanities and promotes self-consciousness and self-empowerment of Ukrainians, as well as their communication with the world cultural heritage.

Keywords: classic, sixtier, sources of works, spiritual stoicism, Old Ukrainian epoch, Ukrainian, Baroque, individual style, Neo-Baroque, travesty, convention, historiosophy, parabolic features.

Безнастанна моя праця позбавила мене вільного часу, розваг, але дала мені інше: радість, яку відчуває садівник, коли дивиться на свій плодоносний сад, адже й плодоносить він завдяки його праці, отож, щоб сад жив і ріс, треба до нього прикласти рук.

Валерій Шевчук

Валерій Шевчук належить до тих небагатьох українських письменників, наших сучасників, чию величезну багатогранну творчу спадщину неможливо 


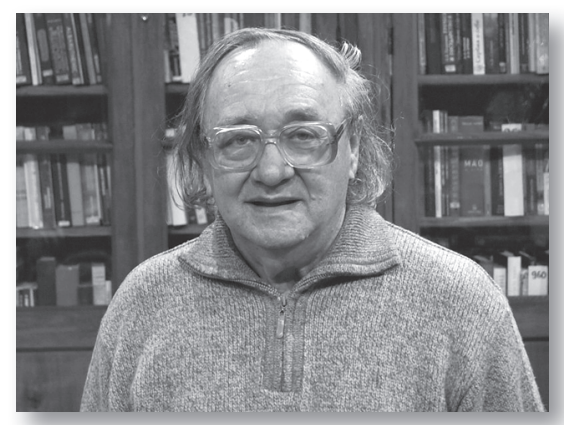

Валерій Шевчук на презентації другого тому книги “Наш Лукаш" у Києво-Могилянській академії. (2011). Світлина Андрія Макухи. так просто, легко осягнути, глибоко пізнати й зрозуміти, а тим паче вичерпно дослідити, описати й оцінити в істориколітературному, інтертекстуальному, суспільному й метафізичному контекстах, хоча спроби такі постійно з'являються, іноді й небезуспішно. Річ у тім, що його творча діяльність, розпочавшись раніше від першої друкованої в 1961 р. новели "Настунька", не вичерпується й донині, тобто триває майже 60 років. Кожний новий дослідник відкриває й оцінює по-своєму грані його творів, бачить ті чи ті актуальні для свого часу контексти, акцентує різні проблеми й художні особливості.

Він народився напередодні Другої світової війни, жив у період “культу особи”, стартував як письменник у період “хрущовської відлиги”, гідно перетривав ганебні радянські роки, здобув нове дихання в часи незалежності, не збавляє творчого потенціалу й у нинішньому “гібридному" державотворенні України. За цей час йому судилося бути поетом-індивідуалістом і прозовим побутописцем, реалістом і модерністом, іронічним філософомекзистенціалістом, історичним белетристом, ментальним психологом, представником українських шістдесятників, акумулятором “житомирської прозової школи", необароковим предтечею українських постмодерністів. От лише назвати Валерія Шевчука радянським письменником ніяк не можна. Адже він завжди залишався вірним собі та власним переконанням, зі своїми сцецифічними темами, героями, не пов'язаними з кон'юнктурою чи партійними настановами, зі своїм неповторним індивідуальним стилем, що не вкладається в жодні канони, зі своєрідним, “шевчуківським" змістовим наповненням, оригінальною, незалежною думкою-ідеєю, зазвичай захованою в образі, художній деталі, притчовому підтексті, переданою через композицію, долю чи поведінку героїв, їхні характери, підказаною назвою, сюжетом.

Він випробовував і стверджував себе в різних жанрах поезії, прози, драматургії, кінодраматургії, у науковому й есеїстичному літературознавстві, критиці - як письменник, історик, історіософ, культуролог, літературознавець, архівіст, перекладач, укладач антологій і збірників, мемуарист, бібліофіл. Така розмаїта творчість В. Шевчука як митця й громадянина пов'язана з розумінням ним особливостей письменницької праці, зі сповідуванням вільного саморозвитку й творчої діяльності людини, відповідності їх її внутрішній “природі”.

Чи не тому керувався своєю душевною потребою, власними уподобаннями, відкриттями в царині давньої, нової й модерної української історії, історіософії, літератури, але завжди й розумінням значимості плодів своєї творчої праці для українського народу, його самоусвідомлення й самоствердження, комунікації з надбаннями скарбниці світової. Це також було й залишається незмінною внутрішньою настановою письменника. Під час вручення йому 1991 p. премії Фундації Омеляна і Тетяни Антоновичів за роман “Три листки за вікном" сказав: “Моя доля як митця не складалася безхмарно, але я ніколи на неї не нарікав. Ніколи не шукав слави для себе, але шукав слави для народу свого і своєї літератури. Зрештою, я й полюбив народ свій через те, що він був упосліджений, гнаний, битий і обкрадений. <..> Кожен з нас - гість у цьому житті, але кожен у ньому, як уміє і як може, будує свій храм..." [1, 50-51]. 
У творчій долі Валерія Шевчука важливе, центрове місце (кожне своє) займають два міста, які він уважає рідними: Житомир і Київ. Ці міста він сприймає не лише як конкретні “географічні поняття", а і як своєрідні образи, "витворені" його внутрішнім єством, свідомістю.

Житомир - місто, де він народився 20 серпня (насправді 19-го, о 23.30) 1939 р. в родині шевця. Воно було містом його "предків та дитячо-юнацьких вражень", постійно живе в його серці, це "місто його душі" - без нього "не існував би як український письменник" [14, 14-17, 24]. Тут жили й поховані його батьки, старший брат Анатолій (письменник-шістдесятник). Очевидно, від батька йому передалися одержимість працелюбством і органічне несприйняття будь-якої влади. Пише про нього так: "Він був великий трудівник, і я ніколи не пам'ятаю його при безділлі - і після роботи шив взуття, сидячи на своєму пасмастому стільці. Жили ми дуже бідно. При роботі вельми любив, коли мати читала йому українську класику, улюбленими його письменниками були І. Нечуй-Левицький та Панас Мирний. Отак вони допізна засиджувалися: він шевцював, а мати йому читала. Я згадую цей фракт, бо він пробудив у мені інтерес до української літератури" [16, 340-341]. Не менший вплив на нього мала й мати, полька за походженням, але українка за самоусвідомленням. Вона розмовляла правильною українською, найбільше любила українську класику й над усе прагнула дати добру освіту синам, тому була до них вимогливою. Крім того, "завжди казала, що зовні та й характером, навіть певними звичками й уподобаннями" він дуже схожий на рідного “діда Франца”, який “чудово співав українських пісень, мав темно-сині очі” [16, 337].

Із Житомиром назавжди пов'язані його юначі пошуки себе, змужніння й початок наполегливої самоосвіти. Навчаючись у 32-й середній школі, Валерій Шевчук усерйоз зацікавився геологією: за колекцію каміння на Всесоюзній сільськогосподарській виставці отримав “медаль її учасника"; працював у геологорозвідувальній партії в с. Рижани біля Володар-Волинського. Однак у геології швидко розчарувався й після закінчення школи спробував вступити до Львівського лісотехнічного інституту. Довелося перепробувати різних робітничих професій у Житомирі, урешті, закінчив там Житомирське технічне училище №1 і рік працював на бетонному заводі. Дедалі більше його вабив столичний Київ. Однак назавжди осівши там, постійно, особливо влітку, навідується до своєї “хати маленької”, зведеної понад сто років тому в “Долині джерел”, “де зливаються річки Кам'янка й Тетерів" [13, 3-5], “біля якої ростуть три могутні дуби" і яка стала для нього “осереддям землі" [14, 24]. Там він "народжувався спершу як поет, а потім як прозаїк" [13, 23], там писав чимало своїх творів - туди повертається за натхненням і спочинком, цілющою енергетикою рідного дому, місцевими новинами. Не дивно, що прототипами багатьох його героїв стали саме житомиряни: батьки, родичі, знайомі, друзі, сусіди. Дія в більшості творів про сучасників відбувається також саме там, у різні часи; побутовий колорит Житомира, особливо буттєва аура його околиць, виписані в них досить ретельно, хоча й із великою дозою умовності та авторської франтазії, а то й іронії, власне, "значною мірою вони про Житомир і про його людей” [14, 24]. У цьому переконує й родинна хроніка Валерія Шевчука "На березі часу. Мій Житомир. Хата і рід" (див. також: [12]), слушно позиціонована ним як "автобіографрічна оповідь-есе", бо все в ній переломлене крізь призму суб'єктивного сприйняття, свідомості й пам'яті, що вирізняє найважливіше, найхарактерніше й закарбовує назавжди як матеріал для образного перетворення.

Житомир у прозі В. Шевчука загалом посідає досить поважне, якщо не головне місце, постає узагальненим цілісним образом. Він також слугує одним із необхідних джерел сюжетів, життєвих історій, ритуалів, звичаїв 
і традицій, навіть більше - невід'ємний від процесів образотворення й характеротворення, бо вихоплені з пам'яті деталі, обриси реальних людей допомагає "переплавити" в художні. Як пише В. Шевчук, "Це місто має особливі чари. Його спокій породжує творчий неспокій, його краса спонукає до творення красивого та вічного" [14, 23].

Ось такий Житомир, очевидно, породив у ньому спершу поета - ще десятикласником почав віршувати, наслідуючи брата. Переважна більшість саме тих віршів не збереглася, але писав він їх упродовж усього життя, надалі ретельно приховуючи це від читача. Житомир сприяв формуванню його художньої свідомості на поетичній основі. Згодом М. Павлишин, автор однієї з перших і донині найцікавіших студій над романом-баладою "Дім на горі" (уперше надрукована в журналі “Сучасність”, 1987, №11), слушно говорив про поетичність як особливість ідіостилю письменника ("Його проза великою мірою поетична"). Адже читач усвідомлює наповнення "слів і речень" символічним і асоціативним значеннями, у нього виникає "враження невипадковості", відчуття того, "що кожна річ чи явище $є$ не тільки собою, а також символом, що кожний образ має своє місце в обдуманій загальній системі" [9, 103]. Крім того, у період свого становлення В. Шевчук мав кілька "найбільших відкрить", “поетичних потрясінь": “першим поетичним кумиром" іще в Житомирі став Г. Гайне; збірка "Червоний заспів" В. Чумака "струснула й цілком змінила" його "бачення й розуміння поезії як мистецтва" [16, 353]. Уже в Києві, вражали модерні вірші А. Кримського, Є. Плужника, В. Свідзінського, "японська й давньокитайська поезія", що мала "тонкість поетичного малюнка". Із прозових "відкрить" - "оповідання В. Підмогильного з його екзистенційними настроями" [16, 359], В. Винниченко, К. Гамсун. Згодом, 1963 р., у Львові, коли В. Шевчук гостював у братів Горинів, його вперше вразив Б.-І. Антонич - як "щось воістину нове та грандіозне". Але "найпершим життєвим учителем, який дав йому "школу в поезії", був Борис Тен, житомирський інтелектуал, "душа" "обласного літературного об'єднання”, перекладач “Одіссеї” та “Іліади”, античних трагедій, європейської поезії, а ще композитор і хоровий керівник.

Літературний же кругозір Валерій Шевчук по-справжньому розширив і поглибив таки в Києві, куди перебрався 1958 р., ставши студентом історикофрілософського фракультету Київського університету й отримавши регулярний доступ до столичних бібліотек, книгарень (перетворившись згодом у вірного бібліомана), беручи активну участь у зібраннях тодішньої патріотичної творчої молоді, яку назвуть шістдесятниками й дисидентами.

"Моє рідне місто - Київ", - наголосить він уже в поважному віці. I присвятить йому одну з книжок "спогадового циклу" ("На березі часу: Мій Київ. Входини" (2002). Виринатиме його особливий образ також у багатьох художніх творах. Найголовніше - це місто дало йому можливість “збутися як митцеві". Він приїхав сюди дев'ятнадцятирічним, спраглим до знань і відкриттів, тому одразу кинувся пізнавати, "вживатися" в нього, пішки блукаючи його вулицями, парками, дозволяючи трамваям, тролейбусам “закидати” в “глибинні закутки”, студіював книжки про нього, записував почуті розмови, відвідував кав'ярні, їдальні, бібліотеки, театри, виставки. Зізнається: “Поступово почав відчувати ритм міста, задихав ним, а воно задихало мною. І я почав жити в ньому як риба, бо воно стало мені отією "водою”, отим киснем, необхідним для дихання" $[14,14]$. Тут знайшов друзів, дівчину, яка стала дружиною й народила йому дітей, "почав писати про людей із вулиць цього міста" прозою, і саме як прозаїк ствердився, з головою поринувши в життя його "літературної богеми".

Однак скрізь у Києві його супроводжувала поезія, бо душа постійно жила напружено, у міському ритмі, емоційно, настрої змінювалися відповідно до великих і малих подій, які ще й тиснули; настрої змагалися із сум'яттям і 
розчаруванням, часом додавали впевненості, надихали й породжували відчуття внутрішньої свободи, розкутості й розкрилля, потрібності людям і самому собі також. Ці вірші Валерій Шевчук, нарешті, наважився укласти в чималу книжку "Місто Днів" (2015) - а це місто Київ, доповнивши їх поетичними перекладами; то була подія для його відданих читачів, бо письменник насправді оголив свою душу, оприявнив своє інтимне, особисте, глибоко заховане від сторонніх. Критика цю збірку майже не помітила, бо звикла бачити Шевчука могутнім велетнем духу, титаном величезної творчої праці, недоступним класиком, і аж ніяк не сподівалася відкрити в ньому тонкого, чутливого поета-лірика. А він усе життя відокремлений і самотній у своїй величі титана (чи то міф?) насправді перебуває у вежі зі слонової кістки. I це підтверджує його поетична книжка. Цей діаріуш душі, ліричний щоденник, у якому зібрано поезії від 1955 р. до 2013-го, власне, писався впродовж усього творчого життя. Тут - записи душевних станів, різних настроїв, передано відчуття, почуття, переживання, душевні страждання, також зачудування світом; це спроба зрозуміти себе в ньому, знайти відповідь на сакраментальне: бути чи не бути? I жодного пафосу тієї радянської доби, який проголошували його сучасники. Тут лише про себе, найчастіше мінорно, але не трагічно; тут повне злиття зі своїм ліричним героєм, зазвичай самотнім і задуманим, але чутливим до всіх вітаїстичних принад світу, до його багатоголосся, кольорів, настроїв - усе це поза політикою, суспільними перипетіями.

Така це осінь, стільки кольорів!

Я на листку осіннім граю, немов співак мандрований, - співаю

Про Місто Днів.

Ці рядки написано далекого 1958-го, але в них передано найголовніший стан душі поета впродовж наступних років - наповнений життям і життєлюбством, творчістю й невтамованою спрагою постійної праці й відкриттів. Є в цих Днях і чекання чогось особливого, і радість зустрічі, і гіркота розлуки, утрати - усього, що трапляється на життєвій дорозі.

Тут переважають ліричні медитації-роздуми (чи розмови із собою), у яких автор висновує власне розуміння світу, життя, непоспішно наближаючись до таємниць буття й водночас віддаляючись від них. "Я - самотній подорожній"; "Я не знав, що так можна страждати", "Тож хочеться сховатися від світу / У тишу, спокій, між стежок забитись <...>. I попросити в серце трохи квіту” - за цими рядками вразлива душа, яка прагне гармонії, розуміння, хоче бути почутою. Однак поступово розумієш, що за цими поезіями й самодостатня, вільнолюбна особистість, яка завжди чесно робила свою справу, упевнено йшла по життю й нині може сказати: "Це щастя, що лишаюся собою".

Поезії доповнює розлога авторська передмова (своєрідна історія Шевчукапоета) і коментар фактологічний, спогадовий - там розгадка, опис ситуацій, пояснення причин з'яви того чи того вірша.

Та повернімося до реалій прози життя Валерія Шевчука. На початку 1960-х він уже досить активно друкувався в “Літературній Україні", "Вітчизні", був учасником Всесоюзної наради молодих письменників у Москві, де його зустріли досить прихильно. Помітила й тогочасна критика, щоправда, більше негативними відгуками, бо його твори не відповідали соцреалістичним шаблонам. Та це не зупиняло настирливих пошуків власного шляху в літературі, не змінювало завжди осібну позицію, не стримувало вільного висловлення своїх поглядів. Отже, тавро неблагонадійного Валерій Шевчук отримав цілком закономірно як на ті часи. Його відправлено до армії, аж у Мурманську область. Солдатська служба була відразлива, рятували щоденні листи до дружини, також умудрявся писати, зокрема там з'явився його перший роман "Набережна, 12". 
1965 р. повернувся в Україну, недовго працював у відділі музеєзнавства Державного історичного музею УРСР. Для інтелігенції наставала тривожна пора: закінчувалася доба "хрущовської відлиги", накочувалася нова репресивна хвиля. 4 вересня 1965 р. в кінотеатрі "Україна" під час перегляду фільму "Тіні забутих предків" С. Параджанова група київських інтелігентів підтримала протест проти утисків влади, який виголосив І. Дзюба. У колі сміливців був і Валерій Шевчук. Почалися нові стеження, старший брат уже відбував ув'язнення в Мордовії, обшуки були й у нього, невдовзі залишився без роботи.

І все ж 1967 р. з'являється перша книжка оповідань "Серед тижня", написана також під час служби в армії. Ї̈̈ схвально привітав І. Сенченко. Автора прийнято до Спілки письменників, його оповідання перекладають у Варшаві, Парижі, Москві. Наступного, 1968-го, надруковано під однією палітуркою роман "Набережна, 12" і повість "Середохрестя", що викликало "зливу негативної критики”, хоча, як зазначив М. Павлишин, "У цих творах тонка спостережливість та зацікавленість винятковими психологічними станами ще вкладалися в очевидно реалістичну творчу методику" [9, 98]. Це спостереження стосувалося, власне, усієї ранньої прози В. Шевчука.

Однак 1968 рік став у його творчій долі переломним - починає писати фольклорно-історичні оповідання (зокрема з'явилася “Панна сотниківна”), які згодом увійдуть до “Дому на горі”, повість “Ілля Турчиновський”. А це означало, що він "почав відходити від неореалізму, зануреного у побут, і звернувся до умовних фрорм, хоч і реалізму до решти не покидав" [16, 377-378]. Ця творча манера збережеться в нього назавжди, стане основною рисою індивідуального стилю. I були на те об'єктивні, але й, очевидно, доленосні причини.

Вихід друком 1969 р. книжки оповідань “Вечір святої осені" став для автора фратальним - на неї в Україні не з'явилося жодної рецензії (був лише один відгук у Москві [8]). Для Валерія Шевчука розпочалися "важкі сімдесяті роки", коли письменник потрапив до "чорного списку" і його майже не друкували. Він "пішов у схиму, тобто зачинивсь у келії чи в башті зі слонової кості" [16, 397]. Однак це не знищило в ньому живого митця, а навпаки - сприяло творенню самобутнього художнього світу, хай відчуженого від світу зовнішнього, водночас мінливого й цікавого. Майже всі друзі (крім Є. Поповича, Р. Корогодського, В. Яременка) "відвернулися", але поряд було багато книжок, щоденна праця над давніми манускриптами, власними творами, які писав "у стіл”, без надії опублікування. "Позаду залишалася літературна метушня, змагання, стосунки з видавництвами й періодикою, нервування, захоплення, натомість підійшла врівноважена дорослість...", - коментує ту тяжку ситуацію В. Шевчук, - “...я тоді знав у своєму житті одне: щоденну працю без вихідних та відпусток, знав я і моменти високого духовного ояснення, яке допомагало мені жити; в ім'я тих ояснень і задля них, може, я й жив" [16, 397].

Лише 1979 р., після десятирічної перерви, Валерій Шевчук знову з'являється в літературі; тоді побачила світ його книжка "Крик півня на світанку", куди ввійшли повісті “Голуби над дзвіницею” й “Крик півня на світанку”, написані в 1974-му. Перша з них у видавництві була "жорстко порізана", поправлена задля уникнення претензій із боку “владних структур", через що автор хотів забрати рукопис, але його “умовили того не робити" [16, 406]. 1981 р. вийшли друком книжки “Долина джерел" і “Тепла осінь". Крига скресає вже назавжди. Поступово, часом із труднощами, утручанням редакторів, "пильним пригляданням" цензорів, вишукуванням “крамоли” були надруковані: "На полі смиренному", “Дім на горі”, “Маленьке вечірнє інтермецо”, “Камінна луна", "Птахи з невидимого острова", “Мислене дерево”, "Барви осіннього саду”, “Три листки за вікном”, "Вибрані твори”, “Місячний біль”. Від 1990-х побачили світ “Панна квітів”, “Дзигар одвічний”, “Початок жаху”, “Чортиця”, 
“Місяцева зозулька з Ластів'ячого гнізда", "Стежка в траві. Житомирська сага", "У череві апокаліптичного звіра", “Око прірви”, "Юнаки з огненної печі”, "Жінка-змія", "Срібне молоко”. "Тіні зникомі", "Мор”, "Компанія з пивниці біля Чуднівського мосту", "Сон сподівань віри. Готично-притчева проза”, "Роман юрби", "Привид мертвого дому" та ін. Твори Валерія Шевчука, надруковані в 1980 - 2010-х роках, написані здебільшого в умовах його вимушеної ізоляції від суспільства. Загалом він майже всі свої великі тексти писав упродовж довгого часу. Зокрема, над “Стежкою в траві” працював у 1967 1987 рр., а надрукував - 1994-го. Задумана як сага, епопея про життя "понівеченої української інтелігенції", службовців, робітників, люмпенів його рідної “житомирської околиці” в 1950 - 1960-ті роки, постала як соціальнопсихологічна узагальнена картина життя радянської людини. Водночас це й твір про екзистенційну людину, котра насправді “безпорадна перед долею”, напружено шукає "своєї стежки для втечі від самотності, із зони герметичної духовної ізоляції, у простір добра й любові” $[15,496]$. Подібний глибинний, символічний підтекст притаманний усім його творам, хоча й мають вони локальну, конкретну першооснову.

Пишучи про своїх житомирян і рідний Житомир, лише наїздив туди, а екзистенційно перебував таки в столичному багатовіковому Києві, бо жив там постійно. Він зрозумів, що Київ - "серце його народу", "те святе місце, куди ведуть усі шляхи землі української”, і тому тут йому “захотілося стати людиною саме української культури, бо ця культура тут корінна, бо саме вона тягнеться прямим стеблом із найглибших глибин, пізнати його значення в системі інших міст і поселень, у системі міст та поселень цілого світу" [14, 14-15]. Тому вирішив "вжитись у нього духовно, відчути в собі всі півтори чи дві тисячі років його існування, його багатовікову культуру, корені та прикорені" й “стати тут свідомою часткою могутнього живого організму, з яким мав дихати й мислити в унісон" $[14,15]$. Період десятирічного усамітнення був для нього “чудовим часом", про який згадує ще й конкретніше: "Днями, тижнями, місяцями, роками я пропадав по бібліотеках, у відділі рукописів ЦНБ в Києві", здійснив археографічні поїздки до Львова, Кременця, Острога, Почаєва, Тернополя, Новгород-Сіверського, Кам'янця-Подільського, де читав, перекладав, досліджував давні манускрипти періоду Київської Русі, XVI - XVIII ст. $[16,398]$. Наслідком цієї скрупульозної багаторічної роботи стали антології “Аполлонова лютня. Київські поети XVII - XVIII ст.", “Пісні Купідона. Любовна поезія на Україні в XVI - поч. XIX ст.", "Антологія української поезії. Том 1. Поезія XI - XVIII ст.", “Марсове поле. Антологія героїчної поезії на Україні від XI - поч. XIX ст." (у 2-х томах); переклад, упорядкування, творів Г. Сковороди, І. Вишенського, Л. Барановича, І. Величковського, Д. Братковського, "Літопису Самійла Величка" у 2-х томах (“найбільший український літопис", на 100 др. арк.), "Катехізису" П. Могили та ін.

Перед ним відкрилася "ціла загублена культура", особливо вразили манускрипти й стародруки давньоукраїнської епохи, зокрема барокова поезія це "складне, вишукане, надзвичайно розумне мистецтво. Бо поезія тоді була не мовою чуття, як тепер, а мовою розуму. Через це мислительні ігри там були дивовижно вишукані і складні”; крім того, це була барокова доба XVI - XVIIIст., коли "ссрормовано остаточний образ українця. Там ще не було російського накипу" [6, 11-12], як каже про нього В. Шевчук, що живило й власні художні пошуки. "Легкий” неореалістичний стиль його прози почав зникати, "бароковіти", ставав дедалі важчим, складнішим, напруженішим, "монументальнішим, 3 розлогим епітетом і складними синтаксичними конструкціями”, "химернішим" його "почали вабити вишукані, ускладнені сюжетні конструкції й великі епосові фрорми" як "структури образні, подібні до вибагливих барокових структур та 
споруд" [16, 399]. У такий спосіб він став трансформатором саме української барокової традиції, досить потужної в XVI - XVIII ст. Як зазначає один із перших її дослідників [3] у незалежній Україні (про що за часів УРСР не могло бути й мови) А. Макаров, "Українська нереалістичність художньої творчості в Україні завжди відзначалася багатством умовних форм <... . Перед тим, як піти з кону культурного життя, барокові інтелектуали встигли прищепити своїм сучасникам і нащадкам смак до високої поетичної умовності". Він наголошує на "ступені поетичної умовності, франтасмагоричності" як вимірі українськості того чи того твору, не кажучи про барокові теми, проблеми, мотиви, образи в ньому [4]. Чим у такому контексті є сучасні твори Валерія Шевчука історикофрілософської проблематики?

Чимало сюжетів, тем, мотивів, образів він безпосередньо запозичує чи використовує з біблійних легенд, переказів, давніх історико-літературних манускриптів, фольклорних джерел - загалом любить травестувати (а це “поширена практика бароко"). Такими травестіями $€$ його романи й повісті "На полі смиренному", “Три листки за вікном" (перша і третя частини), "Дім на горі”, “Птахи з невидимого острова”, “Сповідь”, “Мор”, “Око прірви”, “Початок жаху", "Біс плоті", "Закон зла" тощо. У них можуть діяти й історичні особи, описуватися чи згадуватися реальні події та факти; безумовно, ці твори дотичні до історичної тематики, але дуже специфічно. По-перше, їх використано не лише як будівельний матеріал, привід до ширших історіософрських роздумів, узагальнень про давноминулий світ; автор переглядає й випробовує усталені релігійні істини, загальнолюдські моральні цінності, категорії. По-друге, його художня оповідь часто перетворюється на історіософське й антропологічне міні-дослідження не так певної епохи, суспільства, як свідомості та психології тодішньої людини в історичному контексті. Крім того, внутрішній стан цієї української людини психоаналітично перегукується з його власними відчуттями й станами. М. Павлишин слушно зазначає: "Шевчук не тільки розширив діяпазон потенційних естетичних інтерпретацій минулого, а й спричинився до узаконення складнішого й цікавішого образу історії української культури, в якому доба бароко з її культурною своєрідністю та політичною автономністю отримує гідне місце" $[10,153]$. Навіть більше - письменник "пропонує читачеві матеріяли, спроможні фрормувати нову українську культурну ідентичність або й нові українські культурні ідентичності", він “шукає альтернатив до влади як такої" - через "втечу від структур світу, бароковий ідеал" [10, 154]. Дослідник підсумовує: "Його новаторство полягає в тому, що він не відкидає, а привласнює старі дискурси і використовує їх для того, щоб естетично та інтелектуально збагатити національну літературу" [10,154]. Варто додати: і українську людину, заблукану в довготривалих пошуках себе.

Показовий у цьому контексті роман "На полі смиренному" з наскрізним мотивом сумніву, пошуку, вибору; тут простежено епоху “молодого" християнства в його протиборстві з язичництвом, порушено проблему суперечності між церковними догмами і живою вірою, є роздуми про вічні загальнолюдські проблеми. Та не менш інтригує й запропонована умовна "модель замкнутого тоталітарного суспільства”, від тягаря якого митець так прагнув звільнитися, коли створював цей роман (“Писався він саме тоді, коли в мені накопичилося чимало відрази до світу. Була то своєрідна психотерапія" [11, 57]). Свого часу критика дорікала йому за неточність художньої інтерпретації "КиєвоПечерського патерика", чим, власне, є цей роман-притча, роман-травестія. Колись $€$. Концевич зауважив: "Його історична проза, завжди залишаючись суто історичною, навіть документальною, проектується на нас, прямо в больові сплетіння, а часом, як у неймовірному влучному випадку зі збірником оповідань про угодників "На полі смиренному" - один до одного на все суспільство 
наше сучасне, з його Святошами, Єреміями прозірливими і навіть зі своїм Лаврентієм, упокорювачем біснуватих..." [2, 372]. Тобто варто говорити про барокову умовність строкатої картини життя в Києво-Печерському патерику, притчовий підтекст кожної історії, спроектований на сучасність. Убираючи своїх героїв в історичні шати, автор підсвідомо думав про нинішній світ, про "неспівмірність чистоти духовного життя із брутальністю державної влади, котра прагне підпорядкувати собі навіть релігійні, духовні сфери” [11, 57]. Крім того, через образ Семена-затворника (прототипом послужив Микита-затворник, із якого було "вигнано бісів", тобто єретичні помисли, він став єпископом Новгорода) В. Шевчук передає власні психологічні стани, переживання, сумніви під час вимушеної ізоляції від тодішнього літературного життя (“Слід моїх особистих емоцій і настроїв там надто відчутний" $[11,57])$.

За історичний роман-триптих “Три листки за вікном” (написано в 1968 - 1981 рр., надр. 1986-го) автора було удостоєно найпрестижніших в Україні нагород: Шевченківської премії та премії Фундації Антоновичів - як за найбільше "мистецьке досягнення". Це також історіософський роман, хоча й має витоки в конкретному історичному матеріалі XVII, XVIII й XIX ст. Тут художньо досліджено “історію української душі” в розрізі трьох культурно-історичних епох: бароко, просвітництва, пізнього романтизму. У пошуках відповідей на вічні питання про сенс буття ця "українська душа" проходить своєрідну еволюцію. Три героїоповідачі (вони також $є$ історичними постатями) Ілля Турчиновський (випускник Києво-Могилянської академії), його онук Петро Турчиновський (випускник цього ж закладу) та Киріяк Сатановський (випускник Київського університету святого Володимира) прагнуть з'ясувати: що є добро, а що зло. Кожен із них по-своєму це робить, але в цьому пізнанні вони мовби переймають естафету один від одного.

Вирушає в життєві мандри непогрішний тілом і помислами Ілля Турчиновський (повість “Ілля Турчиновський”), маючи надію “обійняти світ душею”, добром поборювати зло (а це "мудрість передвічна") і так пізнати сенс буття. Але світ не сприймає його "янгольську чистоту", тому почувається в ньому заблукалим та роздвоєним, так і не сягнувши істини. Його онук писар Петро Турчиновський (повість "Петро утеклий”) продовжує ці пошуки. Його бунт проти чужого, жорстокого світу і зла, що панує в ньому, стихійний і несхитний. Сили душевні Петро черпає із самої природи. У третій повісті “Ліс людей, або "Чорна книга" Киріяка Автомоновича Сатановського" праправнук Іллі Турчиновського гімназійний учитель Киріяк Сатановський уже не здатен до активної дії. Його світовідчування основане на спогляданні й засудженні подій, учинків і помислів людей. Себе ж ніби підносить над цим жорстоким, абсурдним світом, не усвідомлюючи зла в самому собі. Однак вийти йому з “лісу людей" так i не вдається. Отже, у "Трьох листках за вікном" Валерій Шевчук простежує важку, суперечливу історію становлення духовності українського народу, його морально-етичного кодексу впродовж трьох століть, що складає "національну самобутність" - адже, як наголошує в одному зі своїх інтерв'ю, “всі оці тисячу років мільйони індивідуальностей боролися, падали, гинули, зводилися, будували і руйнували не тільки матеріальні цінності, але й себе і свою суть, свою духовну структуру - тільки при цій умові мій народ зміг вижити й скласти в сучасності живу наявну реальність" [1, 42].

Роман-балада "Дім на горі" - своєрідна перлина в українській літературі XX ст. - стала яскравим прикладом необарокового стилю, основаним на бароковому світосприйнятті, що полягало в наверненні людини від буднів, життєвих реалій, проблем до сфери високого, вічного, незбагненного. Умовність, символ, алегорія, гіперболізація, метафора активізують думку, уяву, емоційність і почуття читача, спонукають до роздумів над чимось важливішим, аніж повсякденні проблеми й звичайна метушня. 
Друга частина - "Голос трави" - ніби основа, своєрідне підніжжя барокової споруди. Тринадцять фольклорно-міфологічних оповідань в алегоричній, замаскованій формі розповідають насправді про реальне життя. Часом дослідники вбачають у “Домі на горі" вплив латиноамериканського "магічного реалізму", зокрема творів Габріеля Гарсіа Маркеса, Ізабель Альєнде (“Дім духів"), однак автор це заперечує. Розповідаючи історію написання свого роману, який з'явився внаслідок з'єднання необарокової повісті-преамбули "Дім на горі" з раніше створеним “фольклорно-фантастичним" циклом "Голос трави", зазначає: "українцям <...> властиве таке специфічне художнє мислення - у формі фольклорній, демонологічній; демонологія - це, до речі, не лише "містифікований" погляд на світ, на природу, серед якої живе людина, це ще й образ самої людини. ІЇ̈ уявлень, вірувань <..> Магічний реалізм має в українській літературі надзвичайно глибоку й давню традицію" [11, 58-59]. У цьому він переконався, досліджуючи прозовий фольклор, готуючи унікальну антологію "Задзеркалля. Українська готична новела. I споріднені жанри” (з'явилося 2 прим. (“сигнальні”) у видавництві “Фоліо” 1996 р. з передм. І. Качуровського; упор. В. Шевчука). Використання ним цієї фольклорної поетики також дуже специфрічне, “антигоголівське", що наприкінці 1980-х помітив і М. Павлишин, а трохи згодом сам В. Шевчук пояснював: “Гоголь <...> на фольклор він дивився як на забавку, намагався розважити читача “малоросійською" екзотикою. Моя книжка “Дім на горі" - своєрідна дискусія 3 Гоголем. <...> Фольклор - це частина людської духовності, а не просто химерна вигадка, екзотична забава: засобами фольклорної поетики можна здійснювати надзвичайно тонкий і глибокий аналіз людської душі" $[11,58]$.

Фольклорно-міфрологічна частина в “Домі на горі", отже, не виконує роль екзотичного тла, а привносить у нього своєрідну духовну корекцію як частина світовідчування наших предків. Тому так тісно переплетено тут реальні картини 3 франтастичними, умовними, ірреальними. Життя героїв проходить мовби в якомусь химерному (бароковому) світі, однак суттю своєю подібному до світу реального. У ньому також відбувається боротьба між добром і злом, світлом і тінню, людина постійно шукає сенсу буття, самої себе; у її душі панує страх, непевність, неспокій, роздвоєння, що може погубити - це типові барокові проблеми. Проте, як і барокова людина, усі герої В. Шевчука свідомо чи підсвідомо прагнуть внутрішньої чистоти, гармонії. Образ “дому на горі” біля річки Тетерів, довкола якого розгортаються події повісті-преамбули, також міфологізований, він уособлює своєрідну фортецю нашої духовності, той ідеал, до якого прагне жива душа. Тому не розгаданий до кінця, загадковий і часом недоступний.

Сюжет повісті “учуднено” багатьма бароковими засобами та прийомами. Важливе значення для передачі притчового підтексту має символіка, зокрема кольорів (синій, сірий, жовтий, зелений), образів (як реалістичних, так і умовнофрантастичних). Ця символіка тісно пов'язана зі власне бароковими мотивами: небесної дороги як “символу життєвого шляху", який “провадить до вічності"; самотності, яка водночас $є$ прокляттям і благом - ії̈ по-різному відчувають усі герої твору; оснований на біблійній притчі мотив блудного сина, що передає горе вигнання з рідного дому-фрортеці, утечу від світу, себе й водночас радість повернення - знаходження себе, пізнання законів природи і суспільства. Символ дому в поєднанні із цим мотивом означає своєрідне благо, фортецю, міцну основу, а дорога, яка веде із цього дому, - прокляття (див.: [5]).

Роман-квінтет “Привид мертвого дому” (надр. 2005 р.) являє собою також викінчену барокову конструкцію, змонтовану з окремих фррагментів, навіть різножанрових творів, написаних у 1986 - 2000 рр. та об'єднаних архетипом дому - одним з основних у художній прозі Валерія Шевчука. Тут цей образ також пов'язує минуле із сучасним, як і в “Домі на горі", але має кілька іпостасей, 
виконує кілька ролей. Насамперед це дім як осердя й носій автентичної подоби людини, її природного єства; дім як внутрішній диктат і рушій її вчинків; дім як земля обітована, єдиний захисний притулок заблукалому в часопросторі мандрівникові; а також дім як збудований людиною храм, що може зберегтись, а може й бути понівеченим, утраченим навіки. Але завжди для Шевчука дім $€$ уособленням і часткою самої людини, без нього вона не відбудеться, не реалізується, урешті, не зможе пізнати, зрозуміти й саму людину. У “Домі на горі" письменник із різних боків, у різних хронотопах простежував складні стосунки людини та її дому. У романі “Привид мертвого дому” весь сюжетний плин відбувається в подібних координатах, однак авторська увага зосереджена на фратальній руйнації цих стосунків та фріксації ії наслідків - як притчовому резюме. Художнє осмислення такого образу дому починається з ретельного обстеження конкретного, реально сущого в колишньому часі дому (“привид мертвого дому") і завершується узагальненим образом того зовнішнього світу (світ як дім), який оточує кожного. Адже основна сюжетна лінія підпорядкована наскрізній авторській ідеї, утіленій у символіці назви. Перед читачем постає цілісна картина "світу, який умирає" і сучасна людина, котра прагне в ньому вижити й бути щасливою, прагне пізнати себе.

Тут знову химерно, бароково переплелося реальне, автобіографрічне 3 умовним, уявним, візійним, штучно скомпонованим. Для читача (за винятком особисто зацікавленого чи обізнаного із життєвим шляхом автора) реальна автентичність “будівельного матеріалу” не важлива. Однак досить прозоро прочитується психоаналітична тенденція - письменник ніби прагне зрозуміти себе, підсвідомо заглибившись у своє минуле. Ліричний герой (хоча це й романний текст) як його alter ego уособлює свою органічну маргінальність, тобто своє провисання на екзистенційній межі між різними соціосубстанціями (минулою радянською і нинішньою). Чи знаходить він, а заодно й автор, відповідь на питання: де ж він справжній, істинний, а де імітований - той минулий, який прагне себе зрозуміти, чи той теперішній, який, здавалось би, достатньо дозрів для такого розуміння? Очевидно, це питання міг би поставити собі кожен - у контекстуальному полі цього роману воно відкрите. Це, очевидно, найсуттєвіше - він лишається насамперед якісним художнім текстом, цікавим для сучасників (див.: [7]).

У 2010-х роках з'явилося чимало нових книжок художньої прози В. Шевчука, хоча написаних раніше: “Фрагменти із сувою мойр" (3 кн.), "Порослий кульбабами дворик” (2 кн.), “Картини на провінційному тлі. Невидані романи”, "Свято неділі. Невидані повісті"; збірка поезій "Місто Днів" (про неї вже йшлося). Їх вирізняє реалістична достовірність і зовнішня простота, хоча насправді там ідеться про складні, глибокі речі буття, про звичайну людину, яку автор продовжує пізнавати й намагається зрозуміти. Варто згадати й мемуарну прозу: "Темна музика сосон. Роман. Сад житейський думок, трудів та почуттів. Автобіографічні замітки", "На березі часу. Мій Житомир. Хата і рід: Автобіографічна оповідь-есе", "На березі часу: Мій Київ. Входини”, “На березі часу. Ті, котрі поруч: Спогади про сучасників", "На березі часу. Ti, котрі поруч: Спогади про митців і вчених" та ін.

Менш відомою гілкою творчості В. Шевчука є драматургія - давнє, із часів молодості творче зацікавлення. 2006 р. надруковано чималу збірку “Драматургія" з дев'яти його п'єс. Із них у різний час чотири (“Вертеп”, "Сад”, “Птахи з невидимого острова", “Кінець віку”) поставлено в театрах Києва, Львова, Любліна, Івано-Франківська. Найпопулярнішою була драма “Вертеп” (як універсальна картина світу) - вона бачила світло рампи у львівському театрі "Мета", київському “Театрі на Подолі”, Люблінському театрі ім. Г. Х. Андерсена в перекладі польською. “Птахи з невидимого острова” ставили театр “КІН” і 
Львівський театр ім. М. Заньковецької (під назвою “Вічний раб”). П’єси “Мізерія”, "Панна квітів" і "Страшна помста" надруковані тут уперше.

За творами В. Шевчука знято 6 фрільмів: "Вона чекає його, чекає..." "Повний місяць”, “Химери зеленого літа”, “Чудо в краю забуття”, “Голос трави”, “Місяцева зозулька з Ластів'ячого гнізда".

Доречно згадати й “житомирську прозову школу”, першість у якій правомірно пов'язують із його іменем. Крім того, контури "школи Шевчука" виходять далеко за межі Житомира, поширюються на всю українську культуру. Усе "молоде" прозове покоління 1980 - 1990-х фоомувалося під його впливом. Валерій Шевчук зумів зберегти й розвинути себе (а заодно й національну модерністську традицію) у часи чужорідної експансії, підготувати досить сприятливий ґрунт для українських літераторів, яких називають постмодерністами. На мою думку, саме він - їх предтеча.

Цей ювілейний портрет В. Шевчука був би далеко неповним, якщо не згадати про нього як про історіософа, історика української літератури, культури, уважного дослідника-архівіста й аналітика, упорядника й перекладача багатьох художніх, документальних видань. Він - автор наукових, історичних та історико-культурологічних монографічних студій: “Пізнаний і непізнаний Сфінкс: Григорій Сковорода сучасними очима", "Просвічений володар. Іван Мазепа як будівничий Козацької держави і як літературний герой”, “Козацька держава", "Козацька держава як ідея в системі суспільно-політичного мислення XVI - XVIII ст." (у 2-х т.); упорядник документально-наукових видань: 4 томи (XVI - XVIII ст.) видання "Тисяча років української суспільно-політичної думки", “Україна: антологія пам'яток державотворення, X - XX ст." у 10 т. (т. 3: "Битва за Козацьку державу (XVI - XVIII ст.)”, т. 4: “Спроби реанімації Козацької держави (XVIII ст.)"); художньо-документальних видань: "Київський атеней. Мистецький Київ XVI - XVIII ст.”, “Дмитро Туптало. Житія святих (“Четьї-Мінеї”)” (3 томи), "Малі українські діярії XVI -XVIII ст.”, "Василь Горленко. Українська старовина. Вибрані есе та листи"; видань художніх творів М. Філянського, В. Підмогильного, Б. Грінченка, антології "Дерево пам'яті: книга історичних оповідань" (т. 1, 2, 4), збірок “Українська хата": Поезії 1909 - 1914”, “Що записано в книгу життя" М. Коцюбинського, "Золоте чересло: книга народних ремесел, звичаїв та побуту в Україні, писана Климентієм Зіновієвим, поетом кінця XVII- початку XVIII ст."; автор літературознавчих книжок: "Дорога в тисячу років", “Із вершин і низин: Книга цікавих фрактів із історії української літератури", "Доля: Книга про Т. Шевченка в образах та фрактах", "Муза Роксоланська. Українська література XVI - XVIII ст.” (у 2-х кн.), "Енеїда І. Котляревського в системі літератури українського бароко"; понад 500 літературознавчих та історичних статей, передмов тощо. Валерій Шевчук також переклав не лише багато давньоукраїнських текстів, а й зразки польської (твори К. І. Галчинського, Я. Івашкевича, Галини Журби), норвезької (А. Є. Андерсен), грузинської (О. Чіладзе, Т. Чіладзе, Дж. Чарквіані) поезії.

Такою титанічною працею він цілеспрямовано "заповнює білі плями", "переосмислює відоме” в національному культурному простори, і тим розкриває перед сучасниками, перед світом самодостатність і вагомість нашої культурної спадщини, яка творилася від часів Київської Русі й донині. Скажімо, останнє підготовлене ним видання "Мудрість передвічна. Афоризми давніх українських мислителів XI - поч. XIX ст.” (упор., вступ, прим.) засвідчує великий розумовий потенціал українців як європейської нації.

В. Шевчук згадує 24 серпня 1991-го: “Я тоді сидів перед телевізором, дивлячись, як усе відбувалося, і коли було проголошено незалежність, зі мною сталося щось дивне: сльози градом потекли по обличчю - вперше в житті я заплакав від щастя”. У нього відкрилося “друге дихання”, “працював він тоді 
як скажений" [16, 437], бо на нерозораній ниві української культури ще багато роботи. Нині ж підготовлені до друку зібрання творів Т. Осьмачки (3 томи, зокрема повний, невідомий варіант повісті “Старший боярин”), Галини Журби (3 томи), вибране невиданої прози К. Поліщука, "Задзеркалля. Українська готична новела. І споріднені жанри" (з передм. дослідника світової готики І. Качуровського), том власних ранніх оповідань, "Фенікс воскреслий" (статті про маловідомі сторінки історії української літератури) (2 т.) та ін. чекають на видавців. А Валерій Шевчук і далі щоденно натхненно й цілеспрямовано працює.

\section{АITEPATУPA}

1. Вручення премії Фундації Антоновичів // Слово і Час. - 1991. - № 12. - С. 41-51.

2. Конщевич Є. Таємна зброя Валерія Шевчука// Україна. Наука і культура. - Вип. 25. - Київ: 1991. - С. $371-374$.

3. Макаров А.Світло українського бароко. - Київ: Мистецтво, 1994. - 288 с.

4. Макаров А. Уроки бароко // Аіт. Україна. - 1994. - 10 лют.

5. Мовчан Р. Барокові тенденції в романі Валерія Шевчука “Аім на горі” // Мовчан Р. У пошуках архітвору.Київ: ВА Амитра Бураго, 2018. - С. 330-337.

6. Мовчан Р. Валерій Шевчук, якого я знаю і, мабуть, не знаю зовсім...// Українська мова та література. 1999. - Ч. 13. - С. 11-12.

7. Мовчан Р. Міф і реальність, або Привид мертвого дому Валерія Шевчука // Мовчан Р. У пошуках архітвору. - Київ: ВА Амитра Бураго, 2018. - С. 346-365.

8. Никанорова О. Сюжеты, герои, настроения // Аружба народов. - 1970. - № 12. - С. $268-271$.

9. Павлишин М. “Аім на горі” Валерія Шевчука // Павлишин М. Канон та іконостас: Аітературно-критичні статті. - Київ: Вид-во “Час”, 1997. - С. 98-112.

10. Павлииин М. Мітологічне, релігійне та філософське у прозі Валерія Шевчука// Там само. - С. $143-156$.

11. Пивоварсъка А. Аім на горі. Розмова з Валерієм Шевчуком// Сучасність. - 1992. - № 3. - С. 54-59.

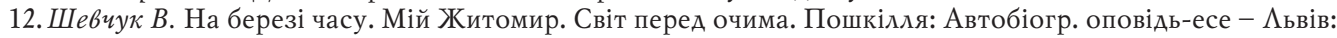
Сполом, 2009. - 478 с.

13. Шевиук В. На березі часу. Мій Житомир. Хата і рід: Автобіограф. оповідь-есе. - Аьвів: Сполом, 2007. $384 \mathrm{c}$.

14. Шевчук В. На березі часу. Ті, котрі поруч: Спогади про сучасників. - Київ: Аибідь, 2016. - 576 с.

15. Шевчук В. Стежка в траві. Житомирська сага. Т. 1. - Харків: Фоліо, 1994. - 494 с.

16. Шевчук В. Темна музика сосон: Роман. Сад житейський думок, трудів та почуттів: Автобіограф. замітки. - Київ: Акцент, 2003. - 448 с.

\section{REFERENCES}

1. Vruchennia premii Fundatsii Antonovychiv (1991)Slovo i chas, 12, 41-51. [inUkrainian]

2. Kontsevych, Ye. (1991) Taiemnazbroia ValeriiaShevchuka Ukraina. Nauka i kultura, 25, 371-374. [in Ukrainian]

3. Makarov, A. (1994) Svitlo ukrainskobo baroko. Kyiv: Mystetstvo. [in Ukrainian]

4. Makarov, A. (1994, February 10) Uroky baroko Literaturna Ukraina. [in Ukrainian]

5. Movchan, R. (2018) Barokovi tendentsii v romani Valeriia Shevchuka "Dim na hori" In Movchan, R. Uposhukakh arkhitvoru, pp. 330-337. Kyiv: Vydavnychyi dim Dmytra Buraho. [in Ukrainian]

6. Movchan, R. (1999) Valerii Shevchuk, yakoho ya znaiu i, mabut, ne znaiu zovsim... Ukrainska mova ta literatura, 13, 11-12. [in Ukrainian]

7. Movchan, R. (2018) Mif i realnist, abo Pryvyd mertvoho domu Valeriia Shevchuka In Movchan, R. U poshukakb arkbitvoru, pp. 346-365. Kyiv: Vydavnychyi dim Dmytra Buraho. [in Ukrainian]

8. Nikanorova, O. (1970, December) Siuzhety, heroi, nastroeniia Druzbba narodov, 12, 268-271. [in Russian]

9. Pavlyshyn, M. (1997) "Dim na hori” Valeriia Shevchuka In Pavlyshyn, M. Kanon ta ikonostas: Literaturnokrytychni statti, pp. 98-112. Kyiv: Vydavnytstvo "Chas". [in Ukrainian]

10. Pavlyshyn, M. (1997) Mitolohichne, relihiine ta filosofske u prozi Valeriia Shevchuka In Pavlyshyn, M. Kanon ta ikonostas: Literaturno-krytychni statti, pp. 143-156. Kyiv: Vydavnytstvo "Chas". [in Ukrainian]

11. Pyvovarska, A. (1992, March) Dim na hori. Rozmova z Valeriiem Shevchukom Suchasnist, 3, 54-59. [in Ukrainian]

12. Shevchuk, V. (2009) Na berezi chasu. Mii Zbytomyr. Svit pered ochyma. Posbkillia: Avtobiobrafichna opovid-ese. Lviv: Spolom. [in Ukrainian]

13. Shevchuk, V. (2007) Na berezi chasu. Mii Zhytomyr. Khata irid: Avtobiobrafichna opovid-ese. Lviv: Spolom. [in Ukrainian]

14. Shevchuk, V. (2016) Na berezi chasu. Ti, kotri poruch: Spobady pro suchasnykiv. Kyiv: Lybid. [in Ukrainian] 15. Shevchuk, V. (1994) Stezhka v travi. Zhytomyrska saba (Vol. 1-2; Vol. 1). Kharkiv: Folio. [in Ukrainian] 16. Shevchuk, V. (2003) Temna muzyka soson: Roman. Sad zbyteiskyi dumok, trudiv ta pocbuttiv: Avtobiobrafichni zamitky. Kyiv: Aktsent. [in Ukrainian] 